AGRO EKONOMI, Vol 29, No 1, Juni 2018, Hal.64-82

DOI : http://doi.org/ 10.22146/ae.30820

ISSN 0215-8787 (print), ISSN 2541-1616 (online)

Tersedia online di https://jurnal.ugm.ac.id/jae/

\title{
THE ANALYSIS OF BUSINESS, RISK, AND DEVELOPMENT STRATEGY OF MINAPADI (PADDY-FISH INTEGRATION FARMING SYSTEM) IN SLEMAN DISTRICT
}

\section{Analisis Usaha, Risiko, dan Strategi Pengembangan Usahatani Minapadi di Kabupaten Sleman}

\author{
Muhammad Nur Prasetyo ${ }^{1}$, Slamet Hartono ${ }^{2}$, Masyhuri² \\ ${ }^{1}$ Magister of Agribussiness, Faculty of Agriculture, Universitas Gadjah Mada \\ ${ }^{2}$ Faculty of Agriculture, Universitas Gadjah Mada \\ Jl. Flora, Bulaksumur, Caturtunggal, Kec.Depok, Kabupaten Sleman, \\ Daerah Istimewa Yogyakarta \\ prastnoer@yahoo.com
}

Diterima tanggal: 24 November 2017; Disetujui tanggal : 22 Maret 2018

\begin{abstract}
This study aims (1) to determine the income and feasibility of cultivation business using minapadi system (2) to know the level of cost risk, income and profit of farming minapadi, (3) to know the development strategy of cultivation using minapadi system in Sleman District of Yogyakarta. To analyse and interpret the data, it used descriptive analysis method. The location of the research was determined purposively it was in Seyegan Sub District. The number of respondents in this research was 43 farmers which consist of 23 minapadi farmers and 20 non minapadi farmers. The analysis used in this research was income, feasibility, risk and SWOT analysis. The result of the analysis showed that the income and profit of minapadi farmers are more than the non-minapadi farmers. The feasibility analysis of farming system in conducting the cultivation using minapadi system and non minapadi system respectively at 1.43 and 1.27 , so that these two businesses are worthy to run since the value of $\mathrm{R} / \mathrm{C}$ ratio was more than 1 . The risk analysis shows that in the farm integrating minapadi has lower risk of costs, revenues, and profits. The appropriate strategy for the development of minapadi farming is the S-T strategy which is by utilizing the strengths to minimize the threats.
\end{abstract}

Keywords: Business Analysis, Development Strategy, Minapadi, Risk

\section{INTISARI}

Penelitian ini bertujuan untuk (1) mengetahui pendapatan dan kelayakan usaha budidaya dengan sistem minapadi, (2) mengetahui tingkat risiko biaya, pendapatan dan keuntungan usahatani minapadi, (3) mengetahui strategi pengembangan budidaya dengan system minapadi di kabupaten Sleman Yogyakarta. Metode data yang digunakan yaitu metode deskriptif analisis. Penentuan lokasi ditentukan secara sengaja (purposive sampling) di Kecamatan Seyegan. Jumlah responden dalam penelitian ini sebanyak 43 orang petani terdiri dari 23 petani minapadi dan 20 petani non minapadi. Analisis yang digunakan dalam penelitian yaitu analisis usahatani, analisis kelayakan, analisis risiko dan analisis SWOT. Hasil analisis menunjukkan bahwa pendapatan dan keuntungan petani minapadi lebih banyak dibandingkan dengan non minapadi. Analisis kelayakan usahatani dalam melakukan budidaya dengan sistem minapadi dan non minapadi 
berturut-turut sebesar 1,43 dan 1,27 sehingga kedua usaha ini layak dijalankan karena nilai $R / C$ ratio lebih dari 1. Analisis risiko menunjukkan bahwa dalam usahatani dengan sistem minapadi risiko biaya, pendapatan, dan keuntungan lebih kecil dibandingkan dengan usaha non minapadi. Strategi yang sesuai untuk pengembangan usahatani minapadi yaitu strategi S-Tyaitu memanfaatkan kekuatan yang dimiliki untuk meminimalkan ancaman yang ada.

Kata kunci: Analisis Usaha, Minapadi, Risiko, Strategi Pengembangan.

\section{INTRODUCTION}

The agricultural sector has a strategic role in the realization of food security at the national, regional, up to the household level. Among the many types of food, rice is still a staple food for most people of Indonesia. A program to increase food security is directed to meet the national food needs of the community. The Indonesian government tries to meet the rice needs of domestic production by making self-sufficient rice as a national policy. The basic problem exists for the farmers is the low farmer income because most farmers only have narrow field.

One way to increase the farmers' income without leaving rice cultivationis by planting using minapadi system. Sularno and Jauhari (2014) in their research suggest that the agribusiness of minapadi can increase the net income by $35.29 \%$. The need for fish in Yogyakarta which tends to increase resulted in the addition of fish supply from outside Yogyakarta. Fish production in Yogyakarta has not been able to meet the needs of fish in Yogyakarta province. Fish consumption needs in Yogyakarta from year to year increase continuously. In 2015, fish consumption in Yogyakarta is $24.68 \mathrm{~kg} / \mathrm{kap} /$ year. The fulfillment of fish needs in Yogyakarta Province is currently derived from the capture fisheries and the aquaculture fisheries.

The high demand of fish that is not balanced with the availability of fish in Yogyakarta is a serious problem to be noted. Although, the existing data states that the growth of fish production in Yogyakarta is rapid, the production has not been able to meet the needs of fish in Yogyakarta. One of the producers of cultivated fish in Yogyakarta Province is Sleman Regency.

Cultivation using minapadi system at this time is the most preferred method since the farmers will obtain higher profit. The practice of cultivation using minapadi system is one example that can be seen in Sleman District. Sleman District has a land that almost the entire of it gets irrigation so that the availability of water is quite abundant and makes the farmers of the area can do the cultivation using minapadi system considering the water sufficiency is an important factor in conducting this 
cultivation. According to Supartama et al. (2013) use of water is one of the most important factors in the field of agriculture. The availability of good water in the paddy fields will allow the utilization of the means of production to be more incentives, in addition the absorption of nutrient elements become more effective so as to provide greater productivity (Tahir et al., 2011). Ghofur (2017) argued that fish farming by utilizing irrigation water will obtain a better result.

Farmers who cultivate rice using minapadi system will get two advantages of earning income from rice or from fish. According to Hermawati (2016), the cultivation with two commodities will increase farmer income and also reduce the risk of crop failures as well as market risk mainly by the prices of the products and means of production. When one type of plant harvested failed, farmers still have other products that are harvested. But cultivation using this minapadi system has a high risk whether it is from the production, cost, income or profit. Costs incurred by the farmers tends to be quite high because in one field, it cultivates two commodities at once. According to Kurniawan (2016) the activities of combining crops cannot minimize the risks compared to the farmers who practice cultivation with just one commodity.

The purposes of this study are (1) to determine the ratio of farmers' income who cultivate rice using minapadi system and non minapadi system, (2) knowing the risk level of cost, income and profit in the practice of cultivation using minapadi and non minapadi system,(2) the strategy development of the cultivation using minapadi system in Sleman District, Yogyakarta

\section{METHODS}

The basic method used in this research was the analytical descriptive method in which the method focuses on solving the problems that exist in the present and on the actual problems. The collected data was initially compiled, described and then analyzed. Seyegan subdistrict was chosen as the research location because it is one of the areas that contribute to the rice production in Sleman District. Seyegan Sub-district is also an area which conducts rice cultivation using minapadi system since 2011 and is a pilot area for minapadi system.

\section{Respondents (Samples)}

Respondents were chosen by using purposive method. The purposive method is the way of taking the research area by considering the reason of the research area. Samples were taken from the farmers in Seyegan sub-district were 43 farmers which consist of 23 minapadi farmers and 20 non minapadi farmers. Samples were taken from various hamlets with the consideration that 
the farmers have experience in cultivating rice crops. The samples of minapadi data taken from 3 hamlets are Mandungan, Cibuk and Kandangan, while for non minapadi samples were taken from Margokaton Village.

\section{Analysis Method}

The data analysis method was used to know how much the comparison of the income of minapadi and non minapadi farmer and to know the feasibility of minapadi business using the farming analysis and then measuring how much the risk of cost, income and profit by using the risk analysis. Further analysis was conducted to find out the proper development strategy in minapadi farming using SWOT analysis (Strength, Weakness, Opportunity, and Threat).

a. The Analysis of farm income and feasibility

Farm costs

The cost of farming is the value of the use of production facilities and others that may be obtained by buying, so that the expenses are in the form of cash but there are also that the means of the production used are derived from the results of the farming itself. Cash costs generally cover fixed costs and variable costs.

Costs taken into account in this study are the costs which actually incurred in minapadi farming, including: the cost of purchasing the production facilities (seeds, fertilizers and pesticides), the cost of purchasing the equipment, the cost of the foreign workers, and the rent of the field. According to Suratiyah (2015), the total cost can be formulated as follows.

$$
\mathrm{TC}=(\mathrm{TFC}+\mathrm{TVC})_{\text {explicit }+ \text { implicit }}
$$

Information:

$\mathrm{TC}=$ Total cost of minapadi and non minapadi cultivation (IDR)

$\mathrm{TFC}=$ Total fixed costs incurred in the cultivation of minapadi and non minapadi (IDR)

$\mathrm{TVC}=$ Total variable costs incurred in cultivation (IDR).

\section{Total Revenue}

The total Revenue (TR) is the product between the production obtained and the selling price. The formula of the revenue by Suratiyah (2015) is as follows:

$$
\mathrm{TR}=\mathrm{Y} . \mathrm{Py}
$$

Information:

$\mathrm{TR}=$ The total revenue earned by the cultivators before the minus costs minapadi and non minapadi farming (IDR)

$\mathrm{Y}=$ The total production of rice and fish $(\mathrm{Kg})$

Py $=$ The selling price of rice and fish (IDR)

\section{Net Revenue}

According to Ely \& Darwanto (2014) Analysis of the income of farming provides 
an overview of the extent to which the level of success in managing a business compared to the average business, land and economic opportunities that exist in the same location in which land and economic opportunities are the same. According to Suratiyah (2015) the formula of farm income is as follows:

$$
\mathrm{NR}=\mathrm{TR}-\mathrm{TC}
$$

Information:

$\mathrm{NR}=$ The Net Revenue from minapadi and non minapadi (IDR)

TR $=$ The total Revenue earned by the farmers (IDR)

$\mathrm{TC}=$ Total Cost incurred by the farmers of minapadi and non minapadi (IDR)

\section{The Farm Profits}

The profit of minapadi cultivation farming is the difference between the revenue and the explicit as well as the implicit costs of the minapadi and non minapadi cultivation or the difference between the production income and the implicit cost. According to Suratiyah (2015) the profit formula is as follows:

$$
\Pi=\mathrm{NR}-\mathrm{TC}_{\text {implicit }}
$$

Information:

$$
\begin{array}{r}
\mathrm{NR}=\text { The Net Revenue of Minapadi and } \\
\text { non minapadi farm income (IDR) } \\
\mathrm{TC}_{\text {implicit }}=\text { The costs which are considered } \\
\text { in the cultivation of minapadi } \\
\text { and non minapadi (IDR) }
\end{array}
$$

\section{Feasibility Analysis of Farming}

To analyze the feasibility of farming, $\mathrm{R} / \mathrm{C}$ ratio analysis was used. According to Suratiyah (2015), R/C ratio can be formulated as follows:

$$
\mathrm{R} / \mathrm{C} \text { ratio }=\frac{\mathrm{TR}}{\mathrm{TC}}
$$

Information:

$\mathrm{TR}=$ The total revenue earned by the farmers before minus minapadi and non minapadi farming costs (IDR)

$\mathrm{TC}=$ The total cost used in cultivation (IDR)

\section{Decision Making Criteria:}

$\mathrm{R} / \mathrm{C}$ ratio $>1$ : The production Cost used by the farmers is efficient

$\mathrm{R} / \mathrm{C}$ ratio $<1$ : The production cost used by the farmers is not efficient

\section{b. Risk Analysis of Farming}

Risk is an uncertain situation which is faced by a person or company that can have an adverse impact. The risk analysis on the cultivation business with minapadi system includes cost risk analysis, income and profit which is done by the means of the coefficient analysis. According to Prihtanti (2014) the value of the coefficient of variation is higher level of risk encountered will be greater than the value of the coefficient of variation is lower. According to Kurniati et al. (2014)to know the risk in conducting cultivation using minapadi 
or non minapadi system, the following

formula can be used:

$$
C V=\frac{\mathrm{s}}{\bar{x}}
$$

Information:

$\mathrm{CV}=$ The coefficient variation cost, revenue and profit risk (IDR)

$\mathrm{s} \quad=$ The standart deviation cost, income and profit (IDR)

$\bar{x} \quad=$ The average cost, income and profits incurred by farmers (IDR)

Statistically, the cost risk can be calculated using variance or standart deviation. Variance is mathematically formulated as follows:

$$
\mathrm{s}^{2}=\frac{\sum_{i=1}^{n}(x i-\bar{x})}{n-1}
$$

Information:

$\mathrm{s}^{2}=$ The variance costs, revenues and profits (IDR)

xi $=$ The cost, income and profits of farmers (IDR)

$\bar{x}=$ The cost, income and average profit of farmers (IDR)

$\mathrm{N}=$ The number of Samples

The Standard Deviation formula is:

$$
s=\sqrt{s^{2}}
$$

Information:

$\mathrm{s} \quad=$ The standard deviation of costs, revenues and profits

$\mathrm{s}^{2} \quad=$ The variance c. Development Strategy

Development strategy of minapadi farming using SWOT analysis. SWOT analysis is used to facilitate the formulation of strategic factors in conducting the cultivation using minapadi system. According to Nutfah (2015) the SWOT analysis comparing between internal and external factors with the assumption that an effective strategy that will maximize the strengths and minimize the weaknesses as well as opportunities and threats.

According to Rangkuti (2011), the SWOT analysis comparing between internal factors (strength and weaknesses) and external factors (opportunities and threats) that will result in four possible strategies, namely:

1. SO strategy (Strengths-Opportunities), the situation is very favorable. An attempt to have the opportunities and strengths that it can capitalize on existing strengths. The strategy should be applied in these conditions is a growth oriented strategy.

2. WO (Weaknesses-Opportunities) Despite facing various threats, an effort still has strength in terms of internal. Strategies that should be applied is a strategy of diversification.

3. Strategy ST (Strengths-Threats), an attempt had a great opportunity but on the other hand are facing the downside of internal side 
4. WT strategy (Weaknessis-threats), is a strategy formulated by reducing the weaknesses while anticipating or minimizing the threats that arise.

\section{RESULTS AND DISCUSSION}

The Analysis of farm income and feasibility

\section{Farm costs}

The cost of farming in this study was divided into explicit costs and implicit costs. Explicit cost is the cost that is used directly in the cultivation process of minapadi or non minapadi. While the implicit cost is the cost that is still economically calculated in the cultivation process, although it is not directly issued by the farmers during a harvest season. Minapadi and non minapadi farming costs per hectare in the Seyegan Sub-District can be seen in table 1 .

Explicit costs in this study consist of fixed costs and variable costs. Fixed costs consist of field rent and depreciation costs of tools used in cultivation. According to Sundari (2011) land is a factor of production that are absolutely necessary in conducting a farming. This is in line with the Thamrin et al. (2013) which suggests that the land is a very important factor because land is where the production process takes place and influence on the magnitude of the resulting production. Tools used were such as hoe, sickle, gosrok (traditional farming tools that work to clean weed pests and soil the ground in rice plants aged 20-30 days), sprayer, tarpaulins, sacks, nets, and mulch. According to Kuheba et al., (2016) depreciation of tools needs to be included in the calculation of the fixed costs. In this study, other costs incurred are implicit costs consist of interest on own capital derived from the interest rate of $9 \%$ multiplied by the ownership of the field and labor costs in the family.

From table 1, it can be seen that the use of the cost used for minapadi farming requires an explicit cost of IDR $36,806,508.07$ per ha and an implicit cost equal to IDR $8,745,598.69$ per ha, so that the total cost incurred by the farmer in conducting the minapadi cultivation that is IDR $45,552,106.76$ per ha. In this minapadi business, the respondent farmers mostly cultivate in their own field. In minapadi business, there are additional production costs beyond the rice farming such as the addition of fish seed and fish feed costs. One success in the conduct of aquaculture is the availability of quality fish seed and feed availability. Most of the costs incurred is the cost of fish feed because the cost is $44.7 \%$ of the total cost incurred by the farmers. In minapadi farming, there is an addition of workforce both within and outside due to the addition of fish farming in the cultivation, for example the installation of nets and mulch as well as feeding fish. Fish feeding is done 
2 times a day. For the cost of the labor outside the family, the payment system is done on a daily basis.

In non minapadi farming, the total cost is IDR $14,128,327.41$ per ha. In conducting non minapadi farming, chemical fertilizers which is used in rice cultivation is much more than the minapadi farming. The use of pesticides in non minapadi farming is also higher than in minapadi. In minapadi farming, the majority of farmers will reduce the use of pesticides because it will affect the growth of the fish. The use of pesticides is done if pest and disease attacks cannot be mechanically resolved. Suharyanto et al. (2015) suggests that pesticide use regardless of the threshold of use will impact negatively. The use of pesticides will increase production costs also would threaten the existence of natural enemies will even improve resistance to pests and diseases

\section{Farming Revenue}

Revenue is obtained from the product between the amount of product produced and the price of the product. Untari (2014) suggests that the magnitude of acceptance depends on the amount of product produced with the selling price of the product. The greater the number of products and product prices then farmers ' acceptance will also be getting bigger. There are two products namely rice and fish in minapadi

Table 1. Average Costs incurred per area of the field (1 ha) per season in minapadi and non minapadi farms

\begin{tabular}{|c|c|c|c|}
\hline No & Description & Minanadj Farmino Cost & Non Minapadi \\
\hline & Explicit Costs & 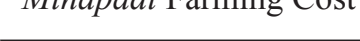 & Farming Cost \\
\hline A & Fixed costs & & \\
\hline & Rent of rice fields & $3,850,241.55$ & $3,350,000$ \\
\hline & Depreciation & $1,401,710.77$ & 486,057 \\
\hline B & Variable Costs & & \\
\hline & 1. Seeds Rice & $689,329.19$ & 532,638 \\
\hline & 2. Seeds Fish & $6,529,626.84$ & \\
\hline & 3. Chemical Fertilizer & $702,587.30$ & $1,245,926.00$ \\
\hline & 4. Pesticide & $5,217.39$ & 140,761 \\
\hline & 5. Organic Fertilizer & $296,739.13$ & 762,532 \\
\hline & 6. Feed Fish & $20,368,543.82$ & \\
\hline & 7. Vitamins / probiotics & $66,086.96$ & \\
\hline & 8. Labor & $2,896,425.12$ & $4,814,694.45$ \\
\hline & $\begin{array}{l}\text { Total Explicit Costs } \\
\text { Implicit Cost }\end{array}$ & $36,806,508.07$ & $11,332,609$ \\
\hline 1 & Capital Interest & $115,507.25$ & $100,500.00$ \\
\hline 2 & Labor in the Family & $8,630,091.44$ & $2,695,218.46$ \\
\hline & Total Implicit Cost & $8,745,598.69$ & $2,795,718.46$ \\
\hline & Total Costs & $45,552,106.76$ & $14,128,327.41$ \\
\hline
\end{tabular}

Source: Primary Data Analysis 2017 
farming products, while the product produced in non minapadi farming is rice. The respondent farmers generally sell their crops directly to the collectors or middlemen. The following is the average of minapadi and non minapadi farm revenue per planting season.

From the table 2, it shows that the revenue of minapadi farming system was higher than non minapadi farming. Minapadi farm revenue was derived from the sale of rice and fish produced in the cultivation business. Rice produced in minapadi farming is higher than non minapadi farming. The yield of rice obtained from minapadi farming is higher by $13 \%$ than non minapadi farming. The dirt from fish cultivation into organic material for soil, results in more fertile fields of the rice fields and more impact on the high production of the rice. The price of paddy produced by minapadi and non minapadi is relatively the same. Farmers sell the majority of paddy products to the middlemen. As for the sale of fish, farmers usually sell it to the groups of farmers or to the middlemen.

Table 2. The Average of Minapadi and Non Minapadi Farm Revenue per Ha per Season

\begin{tabular}{lrrrrr}
\hline \multirow{2}{*}{ Farming } & \multicolumn{2}{c}{ Average Production } & \multicolumn{2}{c}{ Average Selling Price } & \multirow{2}{*}{ Revenue } \\
\cline { 2 - 4 } & Rice & \multicolumn{2}{c}{ Fish } & Rice & \multicolumn{2}{c}{ Fish } & \\
\hline Minapadi & $5,731.83$ & $1,918.63$ & $3,682.61$ & $22,869.57$ & $64,986,329.31$ \\
Non Minapadi & $4,981.92$ & & $3,605.00$ & & $17,959,833.33$ \\
\hline
\end{tabular}

Source: Primary Data Analysis 2017

Table 3. The Average Income and Profit of Minapadi and Non per Ha per Season

\begin{tabular}{rlrc}
\hline No & Description & Minapadi Farming & Non Minapadi Farming \\
\hline 1 & Total of revenue & $64,986,329.31$ & $17,959,833.33$ \\
2 & Total of explicit costs & $36,806,508.07$ & $11,332,608.96$ \\
3 & Total of impicit costs & $8,745,598.69$ & $2,795,718.46$ \\
& Total Costs & $45,552,106.76$ & $14,128,327.41$ \\
4 & Income & $28,179,821.24$ & $6,627,224.38$ \\
5 & profit & $19,434,222.55$ & $3,831,505.92$ \\
\hline
\end{tabular}

Source: Primary Data Analysis 2017

Table 4. The Analysis of Minapadi and Non Minapadi Farming Suggestion per Ha per Season

\begin{tabular}{rlrc}
\hline No & Description & Minapadi Farming & non Minapadi Farming \\
\hline 1 & Total of revenue & $64,986,329.31$ & $17,959,833.33$ \\
2 & Total of explicit costs & $36,806,508.07$ & $11,332,608.96$ \\
3 & Total of impicit costs & $8,745,598.69$ & $2,795,718.46$ \\
& Total Costs & $45,552,106.76$ & $14,128,327.41$ \\
& R/C Ratio & 1.43 & 1.27 \\
\hline
\end{tabular}

Source: Primary Data Analysis 2017 


\section{Income and Profit}

Income in a farm is the difference between the revenues and the explicit costs, while farm profits are derived from the difference between income and total cost consists of explicit and implicit costs. According to Wicaksono (2011), revenue farming is calculated from the receipt is reduced by the cost of production in the form of an explicit cost. The average revenue and income as well as profits of minapadi and non minapadi farms which is obtained per season in 1 ha can be seen in table 3 .

From the table 3, it shows that the total farming income of minapadi per ha is IDR $28,179,821.24$, while the non minapadi farming is IDR $6,627,224.38$ per ha. Minapadi farm income is greater than non minapadi farming system. Minapadi farming results in the form of paddy and fish, which are the factors that result in a higher income and profitability of the farmers. Farmers will receive the income from the sale of rice and fish sales. The price of products that tend to be unstable resulting in farmers will receive higher profits. The profit of farmers if they do the rice cultivation will be higher by 5 times than the profit if they do the non minapadi cultivation. However, the costs incurred in conducting the cultivation should also be taken into account, because in the cultivation of minapadi, farmers will incurred higher costs because of the additional cost for fish cultivation.

\section{The feasibility of farming}

Business feasibility is derived from the division between revenue and total costs incurred in the cultivation business which includes explicit costs and implicit costs. If the ratio value obtained more than 1 then the farming is feasible to run, meanwhile if the ratio value is less than 1 then this business is not feasible to run. The feasibility analysis of minapadi and non minapadi farming can be seen in table 4 .

From table 4 above, it shows that minapadi or non minapadi farms are equally feasible to be cultivated because the value of $\mathrm{R} / \mathrm{C}$ ratio is more than 1 . In minapadi farming, the value of $\mathrm{R} / \mathrm{C}$ ratio is 1.43 which means that the cultivation business using minapadi system is worth to cultivate. The $\mathrm{R} / \mathrm{C}$ ratio of 1.43 means that every IDR 1 incurred will get revenue of IDR 1.43. The value of $\mathrm{R} / \mathrm{C}$ ratio obtained from the business using the minapadi system is greater than the value of $\mathrm{R} / \mathrm{C}$ ratio of non minapadi system that is equal to 1.27. Therefore, it can be concluded that minapadi farming is more profitable compared to the non minapadi farming.

\section{Risk Analysis of Farming \\ Cost and Income Risk}

Farmers in a business would want a high income. This income is derived 
from the results of the explicit expenses incurred in the farm. The greater the value of the cost and income variants generated in the business, then it can be known that the greater the cost risks faced by farmers as well. In the cultivation of agriculture, farmers would expect to get high profits. Profits are the result of reduced receipts and total costs consisting of explicit costs and implicit costs as well. Risk analysis of cost and income of minapadi and non minapadi farming can be seen in table 5 and 6.

From table 5, it shows that the variation coefficient value of minapadi farming is higher than non minapadi farming's variation coefficient value obtained from minapadi farming that is equal to 0.29 . It means that in every IDR 1 the cost incurred in conducting minapadi cultivation, the risk to be borne by the farmer is 0.29 . In non minapadi farming, the variation coefficient is 0.19 . That is, in the IDR 1 cost incurred by the farmers, then there is a possibility of the risk obtained by the farmers is 0.19 . When it is viewed from the variation coefficient, then the level of risk in minapadi farming is higher than non minapadi farming. Ihsannudin (2010) states that the greater the value variance the cost then the higher cost of risk levels is faced. This happens because of the additional costs incurred by farmers in conducting the cultivation, because in doing minapadi cultivation, farmers will incur additional costs for fish farming so that the cost incurred by the farmers is higher.

From table 6 , it shows that the variation coefficient value of minapadi farming is higher than non-minapadi farming. The variation coefficient value for minapadi farming is 0.61 and for non minapadi farming is 0.39 . This means that in minapadi farming, every IDR 1 return obtained by farmers generate risk of 0.61 whereas in non minapadi farming business, every IDR 1 return generated farmers, then the risk level is 0.39 . From the result, it is seen that the standard deviation value of minapadi farming system is bigger than non minapadi farming system, so it can be concluded that minapadi farming is more risky than non minapadi farming. Although minapadi business income risks are higher, farmers will also earn higher income. This is according to Suyati (2015), that the greater the risk taken, the greater the expected returns received.

\section{The Risks of Profit}

In the cultivation of agriculture, the farmers would expect to get high profits. Profits are the result of reduced receipts and total costs consists of explicit costs and implicit costs.

In minapadi and non minapadi farming profit risks as shown in the table 7 , it is known that the variation 
Table 5. The Risk Analysis of Minapadi and Non Minapadi Farming Costs per Ha per season

\begin{tabular}{clrr}
\hline No & Description & Minapadi Farming & Non Minapadi Farming \\
\hline 1 & Average costs & $45,552,106.76$ & $14,128,327.41$ \\
2 & Variance & $173,935,958,908,326.00$ & $7,564,209,902,531.00$ \\
3 & Standard deviation & $13,188,478.26$ & $2,750,310.87$ \\
4 & Coefficient of variation & 0.29 & 0.19 \\
\hline
\end{tabular}

Source: The Primary Data Analysis in 2017

Table 6.The Risk Analysis of Minapadi and Non Minapadi Farming Income per Ha per season

\begin{tabular}{clrr}
\hline No & Description & Minapadi Farming & Non Minapadi Farming \\
\hline 1 & Average Income & $28,179,821.24$ & $6,627,224.38$ \\
2 & Variance & $295,692,499,255,298.00$ & $6,660,708,705,377.78$ \\
3 & Standard deviation & $17,195,711.65$ & $2,580,834.89$ \\
4 & Coefficient of variation & 0.61 & 0.39 \\
\hline
\end{tabular}

Source: The Primary Data Analysis in 2017

Table 7.The Risk Analysis of Minapadi and Non Minapadi Farming Profits per Ha per season

\begin{tabular}{clrr}
\hline No & Details & Minapadi Farming & Non Minapadi Farming \\
\hline 1 & Average profit & $19,434,222.55$ & $3,831,505.92$ \\
2 & Variance & $393,724,290,958,007.00$ & $6,271,909,479,284.85$ \\
3 & Deviation standard & $19,842,487.02$ & $2,504,378.06$ \\
4 & Coefficient of variation & 1.02 & 0.65 \\
\hline
\end{tabular}

Source: The Primary Data Analysis in 2017.

coefficient value on minapadi farming is 1.02 . This means that at each farmer profit of IDR 1, there is a risk of loss of 1.02. In non minapadi farming the coefficient value is 0.65 . This means that at the profit of farmers of IDR 1 , the risk of loss is 0.65 . At the risk of profit, it is seen that the variation coefficient value in minapadi farming is higher than in non minapadi farming. That is, the risk of farming profits of minapadi is higher than non minapadi farming as well. Although the level of risks that exist in minapadi farming is higher, the farmers will get higher profits as well.

\section{Development Strategy}

The data obtained from the farmers who conduct minapadi cultivation are collected and analyzed on internal and external factors and then will be analyzed for these factors to know the strategy that can develop the cultivation using minapadi system in Sleman Regency.

\section{Internal factors}

Factors affecting the internal environment in minapadi farming consist of strengths and weaknesses of it. By knowing the strengths and weaknesses that exist in minapadi farming in Sleman 
Regency, it can be concluded on the IFAS matrix (Internal Factor Analysis system) in the following table 8 :

From table 8 seem that the highest value on the strength that is increasing the production of rice cultivation when doing minapadi. In doing average production culture of rice will increase. Fish feces will become organic fertilizer to soil that is beneficial to the rice plant. According to Tahir et al. (2011) the presence of organic materials in sufficient amount in the long run will increase the soil microbes, so that will increase the efficiency of nutrient supply. If these conditions continue to be maintained, then the country will not land a significant decline of fertility. In addition to the conditions will be more conducive to land caused by the movement of the fish. According to Nariratih et al. (2013) are the source of organic material, organic colloids have many advantages such as being able to provide macro and micro nutrient, metal element that is inhibiting toxins, improve the capacity of supporting water, new energy sources for soil organisms as well as are environmentally friendly so that the presence of organic material can increase the growth and crop yield.

On factors of weakness, a weakness there is highest on capital owned by

Table 8. Matrix IFAS (Internal Factor Analysis System)

\begin{tabular}{lccc}
\hline Indicators & $\begin{array}{c}\text { Item's } \\
\text { quality }\end{array}$ & Rate & IqxR \\
\hline Strengths & 0.0892 & 3 & 0.2677 \\
\hline a. Increase of production of paddy & 0.0728 & 3 & 0.2185 \\
b. Increase of income and profit of farmers & 0.0831 & 2 & 0.1662 \\
c. Weed growth that is reduced & 0.0810 & 2 & 0.1621 \\
d. Soil condition that is more fertile after minapadi cultivation & 0.0779 & 3 & 0.2338 \\
e. The number of water throughout the year at cultivation area & 0.0697 & 2 & 0.1395 \\
f. The reduce of family labor wage & 0.0636 & 2 & 0.1272 \\
g. Reduction in the number of fertilizing chemicals cost & 0.0564 & 3 & 0.1692 \\
h. Safe location from flood & 0.5938 & & 1.4841 \\
Total & \multicolumn{3}{l}{} \\
\hline Weaknesses & 0.0687 & 3 & 0.2062 \\
\hline a. Capital owned by farmers that is limited & & \\
b. The equipments owned by farmers in conducting minapadi & 0.0626 & 3 & 0.1877 \\
cultivation & 0.0338 & 3 & 0.1015 \\
c. Beaver pests that are difficult to overcome & 0.0574 & 3 & 0.1723 \\
d. Farmers who only have a ground rent & 0.0410 & 3 & 0.1231 \\
e. Use of compost becomes more & 0.0667 & 2 & 0.1333 \\
f. A small number of labor coming from the family & 0.0759 & 2 & 0.1518 \\
g. Lack of regular meetings of farmer groups or fisheries groups & 0.4062 & & 1.0759 \\
Total & 1.00 & & 2.5600 \\
\hline The sum total &
\end{tabular}

Source: Primary Data Analysis, 2017 
farmers that is limited. Availability of capital strongly influenced the passage of a farming. Capital in farming minapadi is very large due to the additional capital for fish farming. The majority of farmers make farming as the main job will be difficult to provide a large capital in doing cultivation minapadi. The average farmer using its own capital to suffice the costs needed in cultivation. Difficult access to capital gain is one of the obstacles faced by farmers. Whereas the availability of capital is one of the important factors in the conduct of a business. According to Malta (2011) the availability of capital will affect the ability of farmers in agricultural planning and execution as well as the ability to solve the problems of agriculture and eventually affect agricultural production.

\section{External Factors}

External factors of minapadi farming in Sleman regency consist of opportunities and threats. Once the opportunities and the threats exist in minapadi are known in the farming in Sleman regency, it can be concluded on the EFAS matrix (External Factor Analysis system) in the following table 9:

In the table 9 seem that on the opportunities factor, the highest value is present on the existence of guidance in the conduct of aquaculture. Outreach conducted by the Government will help farmers in doing cultivation minapadi.

Table9. Matrix of EFAS (The External Factor Analysis System)

\begin{tabular}{lrrr}
\hline Indicators & $\begin{array}{l}\text { Item's } \\
\text { quality }\end{array}$ & Rate & IqxR \\
\hline Opportunities & & & \\
\hline a. Local government support in developing minapadi cultivation & 0.0794 & 3 & 0.2381 \\
b. Sale price of cultivated products & 0.0776 & 3 & 0.2328 \\
c. A clear market in the sale of cultivated products & 0.0829 & 3 & 0.2487 \\
d. Counseling from field extension officer in conducting cultivation & 0.0970 & 3 & 0.2910 \\
e. Local government supporting cultivation & 0.0670 & 3 & 0.2011 \\
f. An ease in getting fish feed & 0.0794 & 3 & 0.2381 \\
Total & 0.4832 & & 1.4497 \\
\hline Threats & & & \\
\hline a. The difficulty of providing capital to farmers from financial & & & \\
institutions in providing capital to farmers & 0.1217 & 3 & 0.3651 \\
b. Lack of response from communities around about the existence & & & \\
of minapadi business development & 0.1199 & 3 & 0.3598 \\
c. Fish seedlings that are not sufficient for the cultivation process & 0.1270 & 3 & 0.3810 \\
d. Prices of fish seedlings are relatively high & 0.1481 & 3 & 0.4444 \\
Total & 0.5168 & 1.5503 \\
The sum total & 1.00 & 3.0000 \\
\hline
\end{tabular}

Source: Primary Data Analysis, 2017 
In addition, extension officers will guide farmers to be able to do the process well and true cultivation. According to Sadono (2008) the purpose of the extension is so that farmers know, willing, and able to deal with the problem properly and satisfactorily or otherwise generate an independent farmer is only possible if done approach that prioritizes the human and the process of their learning. On site research the existing extension officers there assisting in the conduct of the cultivation system with minapadi, so that the average farmer succeeded in doing such cultivation. The threat factor in farming fish seedling price minapadi is relatively high. Fish seedlings is one of success in doing farming. Increasing the number of farmers who want to cultivate minapadi result in increased demand for fish seeds. The high demand that is not matched by the availability of fish seeds leads to the high price of fish seeds. In addition, the cultivators who provide fish seeds in the study sites only slightly so that the import of fish seeds from other locations.

To find out the right strategy in minapadi farming development in Sleman Regency based on internal and external factors, there is a reduction between the number of strengths and weaknesses (to know the $\mathrm{X}$ axis) and the reduction between opportunity and threat factors (to know $\mathrm{Y}$ axis).
Table 10. Results of Internal and External scoring factors of minapadi farming

\begin{tabular}{|c|c|c|c|}
\hline No & Criteria & $\begin{array}{l}\text { Weighted } \\
\text { Value }\end{array}$ & Coordinate \\
\hline & Internal Factors & & \multirow{4}{*}{0.408} \\
\hline 1 & Strengths & 1.4841 & \\
\hline 2 & Weaknesses & 1.0759 & \\
\hline & External Factors & & \\
\hline 1 & Opportunities & 1.4497 & \multirow{2}{*}{-0.101} \\
\hline 2 & Threats & 1.5503 & \\
\hline
\end{tabular}

Source: Primary Data Analysis 2017

From the calculation above, it shows that the coordinates $\mathrm{X}$ and $\mathrm{Y}$ obtained are at the point of 0.408 and -0.101 , so that minapadi farming conditions are in quadrant II or in a position of diversification.

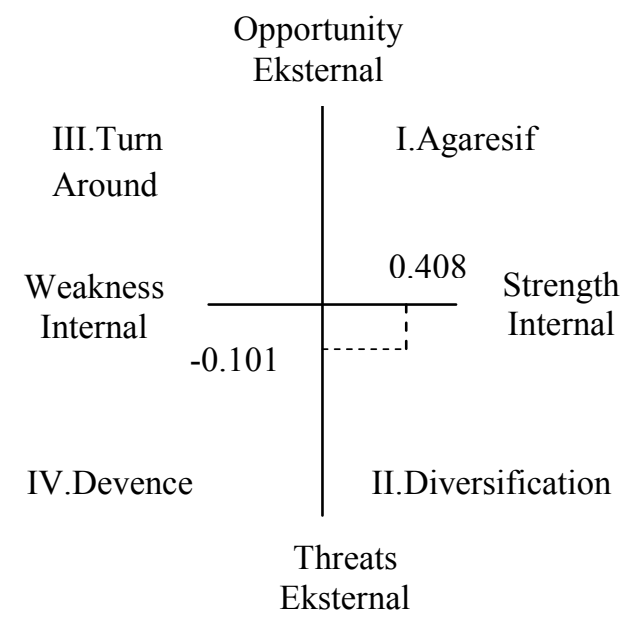

Picture 1.SWOT analysis

Based on the picture above, the cultivation of business minapadi are in quadrant II or in a diversification position. Being in quadrant II means that cultivation using minapadi system has a threat in 
its development but it still has internal strength. The right strategy in doing minapadi farming development is S-T strategy which means to take advantage of its strength to minimize the threats. The development strategy can be done as follows:

Farmer groups establish cooperation with financial institutions (S1,S2,T1)

The number of capital in minapadi farming is one of the obstacles that needs to be paid attention that the considerable cost usage in minapadi farming. The role of farmer groups is important in sustainability of this minapadi cultivation business. The farmer groups are expected to establish cooperation with financial institutions in providing loans to the farmers. The increased rice production and the farmer earnings that get higher can serve as one of the confidence capital to cooperate with the existing financial institutions.

The preparation of self-sufficient fish breeding program $(\mathrm{S} 5, \mathrm{~S} 8, \mathrm{~T} 3, \mathrm{~T} 4)$

Fish seedling is one of a must variable in conducting minapadi cultivation. Constraints often arise in the cultivation simplify like the lack of supply of fish seedlings in conducting the cultivation areas that have advantages such as having the availability of adequate and safe water from floods which can be utilized to provide fish seedlings in the farmer groups in order to supply the needs of fish seedlings required by the farmers. In addition, fish seedlings provided by the farmer groups can reduce production costs incurred by minapadi farmers.

Setting the cropping planting and reviving the system of mutual cooperation between farmers $(\mathrm{S} 3, \mathrm{~S} 6, \mathrm{~S} 7, \mathrm{~T} 2)$

Cropping pattern or timing when the cultivation is one aspect of success in the cultivation since setting the cropping planting can break the chain of pests and diseases that attack the plant. Simultaneous cropping pattern allows farmers to work together to help other farmers in cultivation. The system of mutual cooperation is done in turns so that the communication between the farmers does exist. Therefore, when there are constraints in the area of cultivation, it can be completed together.

Optimizing the role of the farmer groups by distributing minapadi products (S1,S2,T1)

Products produced by the average farmer are still bought by the collectors. Farmer group is expected to be a container to accommodate the products minapadi so that the sale price of these products can be higher. It can also motivate the farmers to meet regularly. The meeting will be utilized 
for the development of minapadi farming system.

Make the village where the cultivation takes place as a pilot village to minapadi $(\mathrm{S} 1, \mathrm{~S} 2, \mathrm{~S} 4, \mathrm{~T} 2)$

The location where the cultivation takes place can be used as a pilot village for the cultivation minapadi. The increase of farmers' income and the increase of rice production are ones of the results that already obtained by the farmers in cultivation. Making a pilot village is also a form of socialization for the farmers around to do the cultivation by using the minapadi system.

\section{CONCLUSION AND SUGGESTION}

\section{Conclusion}

In conducting minapadi farming, the number of earnings and profits of the farmers was higher than doing non minapadi business. In minapadi farming analysis, it does require a high enough cost because of the additional cost for conducting the fish farming. For farming income and profit, the cultivation business which uses minapadi system was higher than the non minapadi.

In the ratio of the feasibility of ( $\mathrm{R} / \mathrm{C}$ ratio) minapadi and non minapadi farming, the value obtained is 1.43 and 1.27 so that these two businesses were feasible to run. The $\mathrm{R} / \mathrm{C}$ ratio of minapadi farming system was higher than the $\mathrm{R} / \mathrm{C}$ ratio of non minapadi farming. Therefore, in conducting minapadi farming, it is more profitable than in non minapadi.

Risk analysis was measured from the variation coefficient value in farming. The coefficient value of variation in cost, income and profit in minapadi farming was higher than in non minapadi farming. This means that minapadi farming is risky than non minapadi farming. Although minapadi farming is risky at cost, income and profit, the farmers will get a higher income and profit compared to non minapadi farming.

In determining the strategy of farming development in Sleman regency, the right strategy position was in quadrant II or in significant diversification position in the development of this minapadi cultivation business using the strength to minimize the existing weakness. The right strategy in developing minapadi cultivation is by using S-T strategy.

\section{Suggestion}

To develop farming minapadi Regency of Sleman, the necessary business development strategies of cultivating. This strategy can be in the form of a group of farmers cooperating with the financial institution, making self-sufficient breeding program, arranging cropping pattern and reviving the system of mutual cooperation among the farmers, optimizing the role of farmer groups by distributing minapadi products, and making the village where the 
cultivation takes place as a pilot village for the minapadi farming system.

\section{REFERENCE}

Ely, A., \& Darwanto, D. H. (2014). Analisis Kelayakan Usaha dan Strategi Pengembangan Budidaya Rumupt Laut di KApupaten Seram Bagian Barat. Jurnal Agro Ekonomi, 25(2), 169-177.

Ghofur, M. (2017). Pemanfaatan Saluran Irigasi Untuk Budidaya Ikan Lele Sangkuriang (Clarias Gariepinus Var Sangkuriang) dengan Sistem Resirkulasi di Desa Pudak Kecamatan Muaro Kumpeh Kabupaten Muaro Jambi Provinsi Jambi. Jurnal Akuakultur Sungai Dan Danau, 2(1), 1-8.

Hermawati, D. T. (2016). Kajian Ekonomi Antara Pola Tanam Monokultur Dan Tumpangsari Tanaman Jagung, Kubis Dan Bayam. Jurnal INOVASI, 18(1), 66-71.

Ihsannudin. (2010). Risiko usahatani tembakau di Kabupaten Magelang. Jurnal EMBRYO, 7(1), 21-28.

Kuheba, J. A., Dumais, J. N. ., \& Pangemanan, P. A. (2016). Perbandingan Pendapatan Usahatani Campuran Berdasarkan Pengelompokan Jenis Tanaman.
Jurnal Agri-Sosioekonomi Unsrat, 12(2A), 77-90.

Kurniati, D., Hartono, S., Widodo, S., \& Suryantini, A. (2014). Risiko Pendapatan pad Usahatani Jeruk Siam di Kabupaten Sambas. Jurnal Social Economic of Agriculture, 3(2), 12-19. https://doi.org/10.14800/ ics. 95

Kurniawan, B. P. Y. (2016). Strategi dan prospek pengembangan jambu mete (anacardium occidentale. L) Kabupaten Jember. Jurnal Manajemen Teori dan Terapan, 9(3), 242-258.

Malta. (2011). Faktor-Faktor yang Berhubungan dengan Kinerja Petani Jagung di Lahan Gambut. Jurnal MIMBAR, 27(1), 67-78.

Nariratih, I., Damanik, M., \& Sitanggang, G. (2013). Ketersediaan Nitrogen pada Tiga Jenis Tanah Akibat Pemberian Tiga Bahan Organik dan Serapannya pada Tanaman Jagung. Jurnal Online Agroekoteknologi, 1(3), 479-488.

Nutfah, S. (2015). Strategi Pengembangan Usahatani Durian (Durio Zibethinus Murr) di Kecamatan Sirenja Kabupaten Donggala. Sains Dan Teknologi Tadulako, 4(3), 85-102. 
Prihtanti, T. M. (2014). Analisis Risiko Berbagai Luas Pengusahaan Lahan Pada Usahatani Padi Organik Dan Konvensional. Jurnal Agric, 26(1), 29-36.

Rangkuti, F. (2011). SWOT Balanced Scorecard-Teknik Menyusun Strategi Korporat yang Efektif plus Cara mengelola Kinerja dan Risiko. Jakarta: Gramedia Pustaka Utama.

Sadono, D. (2008). Konsep Pemberdayaan Petani: Paradigma Baru Penyuluhan Pertanian Di Indonesia. Jurnal Penyuluhan, 4(1), 65-74.

Suharyanto, Rinaldy, J., \& Ngurah Arya, N. (2015). Analisis Risiko Produksi Usahatani Padi Sawah di Provinsi Bali. Jurnal AGRARIS, 1(2), 70-77. https://doi.org/10.18196/agr.1210

Sularno, \& Jauhari, S. (2014). Peluang Usaha Melalui Agribisnis Minapadi Untuk Meningkatkan Pendapatan Petani. Jurnal SEPA, 10(2), 268274.

Sundari, M. T. (2011). Analisis Biaya Dan Pendapatan Usaha Tani Wortel Di Kabupaten Karanganyar. Jurnal SEPA, 7(2), 119-126.
Supartama, M., Antara, M., \& Rauf, R. A. (2013). Analisis Pendapatan dan Kelayakan Usahatani Padi Sawah di SUbak Baturiti Desa Balinggi Kecamatan Balinggi Kabupaten Parigi Moutong. Jurnal Agrotekbis, l(2), 166-172.

Suratiyah, K. (2015). Ilmu Usahatani. Jakarta: Penebar Swadaya.

Suyati, S. (2015). Pengaruh Inflasi, Tingkat Suku Bunga Dan Nilai Tukar Rupiah / Us Dollar Terhadap Return Saham Properti Yang Terdaftar Di Bursa Efek Indonesia. Jurnal Ilmiah UNTAG Semarang, 4(3), 70-86.

Tahir, A. G., Darwanto, D. H., Mulyo, J. H., \& Jamhari. (2011). Analisis Risiko Produksi Usahatani Kedelai pada Berbagai Tipe Lahan di Sulawesi Selatan. Jurnal Sosial Ekonomi Pertanian, 8(1), 1-15.

Thamrin, M., Mardhiyah, A., \& Marpaung, S. E. (2013). Analisis Usahatani Ubi Kayu (Manihot utilissima). Jurnal Agrium, 18(1), 57-64.

Untari. (2014). Analisis Usaha Tani Beberapa Varietass Padi dengan Menggunakan Revenue Cost (R/C Ratio). Jurnal Agricola, 4(1), 1-7. 